\title{
San Precario:
}

\section{A New Inspiration for Labor Historians}

\author{
Marcel van der Linden
}

On

February 29, 2004, the Chainworkers of Milan, an Italian anarcho-syndicalist collective seeking to subvert commercial advertising, chose a new saint: San Precario, the patron saint of casual, temporary, freelance, and intermittent workers. San Precario was initially envisaged as a man but has evolved into a rather androgynous being. He or she can appear anywhere and everywhere: on streets and squares, but also in McDonald's, outlets, supermarkets, and bookstores. ${ }^{1}$ Prayers are directed to the new saint, such as

Oh, Saint Precarious,

protector of us all, precarious of the earth

Give us paid maternity leave

Protect chain store workers, call center angels,

and all flexible employees, hanging by a thread

Give us paid leave, and pension contributions,

income and free services,

keep us from being fired

Saint Precarious, defend us from the bottom of the network, pray for us temporary and cognitive workers

Extend to all the others our humble supplication

Remember those souls whose contracts are coming to an end, tortured by the pagan divinities:

the Free Market and Flexibility

those wandering uncertain, without futures or homes

with no pensions or dignity

Grant hope to undocumented workers

and bestow upon them joy and glory

Until the end of time

I would like to thank Hans Boot, Jan Breman, Jacques van Gerwen, and Alice Mul for our fruitful discussions about this topic and Jurriaan Bendien for his translation work.

I. Marcello Tarì and Ilaria Vanni, "On the Life and Deeds of San Precario, Patron Saint of the Precarious Workers and Lives,” Fibreculture Journal 5 (December 2005), five.fibreculturejournal.org.

Labor: Studies in Working-Class History of the Americas, Volume 11, Issue 1

DOI 10.1215/15476715-2385372 $\quad$ (c) 2014 by Labor and Working-Class History Association

9 
The arrival of San Precario draws attention to a problem of burning actuality: the continuing increase of very vulnerable employees who must live and work in irregular jobs, without any security or predictability. In my provisional and explorative comments here, I argue that this social trend can be understood best if we place it in a global context and broad historical time frame.

\section{Precarity and Its Antithesis}

A broad spectrum of wage-based employment relationships exists in capitalist society. At one end, there is the well-established skilled worker, say a I97os American or Japanese car worker, who has no great fear of dismissal and who, supported by a strong union, can claim substantial labor rights. At the other end, there is the casual worker in the global South, without any rights, whose fate depends on the caprice of the boss and who is not protected against physical and economic abuse by the state, a union, or some other kind of organization. ${ }^{2}$

According to Gerry Rodgers, a former International Labor Organization (ILO) staff member, there are four dimensions that define the location of the worker in the spectrum of wage labor: (I) Time, the extent to which the employee can be sure of continuity of employment (contractual relationship, employment duration); (2) organization, the extent to which employees can individually and collectively exercise control over the work, including working conditions, working time, shifts and schedules, work burden and intensity, pay, and health and safety conditions; (3) payment, both size and expected increase; and (4) protection, the extent to which the employee has legal, collective, or customary protection against unfair dismissal, discrimination, and unacceptable working practices, as well as the extent of access to insurance coverage for illness, accidents, and unemployment. ${ }^{3}$

The one end of the spectrum, at which the employee is well protected and can claim substantial rights, is often called the standard employment relationship. It is usually understood to involve a form of wage labor defined by

- continuity and stability of employment,

- a full-time position with one employer, only at the employer's place of business,

- an income that enables an employee to support at least a small family (the wage earner, a non-employed spouse, and one or two children), without falling below a basic standard of living,

2. Jeffrey Harrod, Power, Production, and the Unprotected Worker (New York: Columbia University Press, 1987), 39-40. For more detail, see Matt Davies and Magnus Ryner, eds., Poverty and the Production of World Politics: Unprotected Workers in the Global Political Economy (New York: Palgrave Macmillan, 2006).

3. Gerry Rodgers, "Precarious Work in Western Europe: The State of the Debate," in Precarious Jobs in Labour Market Regulation: The Growth of Atypical Employment in Western Europe, ed. Gerry Rodgers and Jeanine Rodgers (Geneva: International Institute for Labour Studies, I989), I-I6, at 3. A more refined system of relevant dimensions is offered by Guy Standing, Global Labour Flexibility: Seeking Distributive Justice (New York: St. Martin's Press, I999), 52, I3I-29I. 
- legally stipulated rights to protection and participation or codetermination at work, and

- social insurance benefits, often related to length of employment and the level of previously earned income.

Precarity (precariedad, precariedade, précarité, precarietà, prekarität) is the umbrella term for a range of employment relationships at the other end of the spectrum. The Latin precarius means "uncertain" or "obtained by entreaty." Those living in precarious conditions have no control over their destiny and depend on the goodwill of others; they have no security and are dependent on chance circumstances. ${ }^{4}$ Precariat then refers to the same groups of people who were previously known as the casual poor, those who have both "low average incomes with considerable instability and insecurity of income and employment." 5

All forms of precarious employment relations are temporary, involving jobs that last a day, a week, or a few months at most. Other terms also used for this type of employment are atypical, nonstandard, or contingent. These notions are not exactly defined, ${ }^{6}$ but nevertheless it is reasonably clear what kinds of jobs are included: temporary work via temping agencies; on-call work; work with zero-hour contracts; seasonal labor; casual labor; day labor recruited informally in the open air; intermittent labor; independent contracting; freelance work; internships (college students and recent graduates who work as short-term apprentices, often with a modest compensation for their costs); and many so-called self-employed workers. ${ }^{7}$

The extent to which precarious workers are protected against different kinds of risks can vary greatly. Some are far better off than others in this respect. It is also important to note that not everyone lacking standard employment belongs to the precariat. Teleworkers and part-time workers, for example, may have permanent contracts. Between the two ends of the continuum, there is a middle group that contains many intermediate categories of wage labor.

4. The modern interpretation of precarity seems to have a Catholic background. The term was introduced by Léonce Crenier, a radical monk, and Dorothy Day, cofounder of the U.S. Catholic Workers' Movement.

5. Raymond J. Bromley and Chris Gerry, "Who Are the Casual Poor?" in Casual Work and Poverty in Third World Cities, ed. Bromley and Gerry (Chichester: John Wiley, I979), 5-26, at I4.

6. For attempts at a more precise definition, see Anne E. Polivka and Thomas Nardone, "On the Definition of 'Contingent Work," Monthly Labor Review II 2 (I989): 9-I4; and Polivka, "Contingent and Alternative Work Arrangements, Defined," Monthly Labor Review II9 (I996): 3-9.

7. See, among others, Vicki Smith, "New Forms of Work Organization," Annual Review of Sociology, 23 (1997): 315-339; Arne L. Kalleberg, "Nonstandard Employment Relations: Part-time, Temporary, and Contract Work," Annual Review of Sociology 26 (2000): 34I-65; Abel Valenzuela Jr., "Day Labor Work," Annual Review of Sociology 29 (2003): 307-33; and Guy Standing, The Precariat: The New Dangerous Class (London: Bloomsbury Academic, 20II). 


\section{Precarity's Long History}

Casualized wage labor is not a phenomenon of only the modern era. It has existed for thousands of years. The New Testament, probably written around 200 AD, narrates the parable of "a householder who went out early in the morning to hire laborers for his vineyard" and who, "after agreeing with the laborers for a denarius a day ... sent them into his vineyard." ${ }^{8}$ Often, such day laborers would have regarded their harvest labor only as an addition to income from other sources. Usually, earned wages supplemented income earned by the various household members, from sources such as the following:

- Production of consumer goods for one's own use (subsistence labor). This would include, for example, sewing clothes, raising pigs, chickens, and collecting trash.

- Small-scale production and retail of goods, such as tailoring, raising livestock, collecting rags to sell, or peddling.

- Rental of land, working materials, and living space, including the rental of a bed or room to a boarder or lodger.

- Receipt of money, goods, or services without immediate reciprocity being necessary. This would include the receipt of charity, social assistance and welfare, and support by friends and acquaintances when in need.

When such supplementary incomes were lacking, the condition of the working poor was miserable. In ancient Greece, the landless laborers (singular: thes; plural: thetes) hired for casual work had a very low social status. Since they did not belong anywhere (they were not included in an oikos, a social unit with mutual obligations and a degree of social solidarity), their status was lower than that of domestic slaves. According to the Greek myth, when Odysseus and Achilles met each other in the Hades, Achilles remarked: "Do not speak to me lightly of death, glorious Odysseus. I would rather be bound down, working as a thes for another, by the side of a landless man, whose livelihood was not great, than be ruler over all the dead who have perished." ${ }^{\prime}$ Historian Moses Finley comments: "A thes, not a slave, was the lowest creature on earth that Achilles could think of. The terrible thing about a thes was his lack of attachment, his not belonging." 10

The thetes were the earliest precarious workers, without protection from any organization or institution, but their successors were also regarded as extremely disadvantaged. In the parish petitions of grievances written during the French Revolution, the situation of the day laborer (journalier) was considered as "a kind of hell into which peasants may fall if things are not bettered." 11 And in postmedieval England,

8. The New Oxford Annotated Bible with Apocrypha, eds. Herbert G. May and Bruce M. Metzger (New York: Oxford University Press, 1977), i197 (Matthew 20).

9. Homer, Odyssey, II.489-9I.

Io. M. I. Finley, The World of Odysseus (London: Folio Society, 2002), 46.

II. Sir John Clapham, A Concise Economic History of Modern Britain from the Earliest Times to I750 (Cambridge: Cambridge University Press, I949), 2 I2. 
wage earners with no other income were assumed to be paupers; "only the weakest" would accept such a vulnerable status, "with little or no protection against the sort of abuses which were prevalent in the eighteenth century-truck, delay in payment of wages, and consequent indebtedness." 12

In Western Europe in the fifteenth and sixteenth centuries, the number of landless laborers working in enterprises outside the manorial system and outside the guilds grew. They began to form a class of outcasts. Thus we find, for example, that the tenants of Broseley in Shropshire, England, protested in I6o6 against the opening of a new colliery because they believed it would attract "a number of lewd persons, the Scums and dregg of many [counties], from whence they have bine driven."13

The steadily progressing separation of producers from their means of production led in Europe to a constantly growing proletariat and therefore to larger "dangerous classes" - not only in the cities, as is often believed, but also in the countryside. ${ }^{14}$ In the late 1850 , writer and social researcher Henry Mayhew estimated that in England "out of the $4^{1 / 2}$ million people who have to depend on their industry for the livelihood of themselves and families, there is barely sufficient work for the regular employment of half our labourers, so that only $1 \frac{1}{2}$ million are fully and constantly employed, while $\mathrm{I}^{1 / 2}$ million are employed only half their time, and the remaining $\mathrm{I}^{1 / 2}$ wholly unemployed, obtaining a day's work occasionally by the displacement of some of the others." 15

For a long time, these outcasts were considered part of an amorphous mass of people without honor, which also included beggars, thieves, and prostitutes. ${ }^{16}$ Their lives were constant struggles for survival, without certainty and without possibility

I2. Christopher Hill, "Pottage for Freeborn Englishmen: Attitudes to Wage Labour in the Sixteenth and Seventeenth Centuries," in Socialism, Capitalism, and Economic Growth: Essays Presented to Maurice Dobb, ed. C. H. Feinstein (Cambridge: Cambridge University Press, 1967), 338-50, at 339. For some observations on North America, see Marcus Rediker, "Good Hands, Stout Heart, and Fast Feet: The History and Culture of Working People in Early America," in Reviving the English Revolution: Reflections and Elaborations on the Work of Christopher Hill, ed. Geoff Eley and William Hunt (New York: Verso, I988), 22I49 , esp. $236 \mathrm{ff}$.

I3. John U. Nef, War and Human Progress: An Essay on the Rise of Industrial Civilisation (Cambridge, MA: Harvard University Press, 1950), 23I.

I4. See, for example, Gerhard Schildt, Tagelöhner, Gesellen, Arbeiter: Sozialgeschichte der vorindustriellen und industriellen Arbeiter in Braunschweig 1830-1880 (Stuttgart, Germany: Klett-Cotta, I986), 31-155.

I5. Henry Mayhew, London Labour and the London Poor, 4 vols. (London: Woodwall and Son, I86r), 2:323. About the history of this precariat, there are for the most part only case studies, such as Gareth Stedman Jones, Outcast London: A Study in the Relationship between Classes in Victorian Society (Berkeley: University of California Press, I97I). Longer histories have been written, to my knowledge, mainly in France. See Robert Castel, Les Métamorphoses de la question sociale: Une chronique du salariat (Paris: Fayard, 1995), and Anne-Sophie Beau, Un siècle d'emplois précaires: Patron-ne-s et salarié-e-s dans le grand commerce (XIXeXXe siècles) (Paris: Payot, 2004).

I6. See, for example, Adolphe Granier de Cassagnac, Histoire des classes ouvrières et des classes bourgeoises (Paris: Desrez, I838), 30; and Heinrich W. Bensen, Die Proletarier: Eine historische Denkschrift (Stuttgart, Germany, I847), 344 . 
of planning for the long term. Typical examples of casual labor could be found in the ports along the American and European coasts. In New York's harbor, prior to World War II, "all hiring was done by open shape. Twice a day, at 7:55 a.m. and at I p.m. (and, when necessary, a third time in the evening), the men 'shaped up' in a loose semicircle in front of the pier and were picked for a half-day's work by the hiring or 'shaping boss.' No formal system existed for informing the men where they might be needed from day to day. . . If a man was not hired at the 7:55 a.m. shape, he had little chance of working during the rest of the day." ${ }^{17}$

More generally, it was true for large groups of wage earners "that there is rarely certainty or safety." They would live "shadowed by the consciousness of an uncertain tenure, and there are few whose hearts would not be comforted if the faith upon which their industrial life rests could be based on a fuller knowledge." ${ }^{18}$ Women workers were more often employed precariously than male workers. ${ }^{19}$

\section{The Rise of Standard Employment}

Only the highest strata of the working class could escape from the existential insecurity just described. Among skilled workers in the nineteenth century, the ideal of the "male breadwinner" (or the "family wage") became popular - the idea that the wage of the husband should be sufficient to support a wife and small children. Wally Seccombe explains this development in terms of the increasing separation between home and work during the Industrial Revolution. In the eighteenth century, it was still considered normal that a woman made a significant contribution to the family economy, but that began to change in the nineteenth century when money became more important for household survival and when men, especially, began to earn that money outside the home. "Wage income ceased to include any part which could be attributed to the wife's domestic labour. The product of her unpaid exertions at home was now solely the labour-power of family members, which was consumed elsewhere. With the deepening fetishism of the individuated wage, this intangible product disappeared from sight, and the wage-earner was credited monetarily." 20

I7. Daniel Bell, "The Racket-Ridden Longshoremen," in The End of Ideology: On the Exhaustion of Political Ideas in the Fifties, rev. ed., ed. Daniel Bell (New York: Free Press, I962), I75-209, at I79. For a similar description of casual labor in the London docks, see Beatrice Potter, "The Docks," in The Trades of East London, vol. 4 of Life and Labour of the People of London, ed. Charles Booth (London: Macmillan, I893), I2-36.

I8. Ernest Aves, "Irregularity of Earnings," in Comparisons, Survey, and Conclusions, vol. 9 of Life and Labour of the People of London, ed. Booth (London: Macmillan, I897), 326-6I, at 33I.

19. Raimund Stadlmaier, “'Jede Arbeit ist besser als keine Arbeit!': Prekäre Arbeitsverhältnisse im Kontext wirtschaftspolitischer Paradigmenwechsel im I9. und frühen 2o. Jahrhundert,” in Übergänge und Schnittmengen: Arbeit, Migration, Bevölkerung, und Wissenschaftsgeschichte in Diskussion, ed. Annemarie Steidl et al. (Vienna: Böhlau, 2008), I59-79, at I65.

20. Wally Seccombe, Weathering the Storm: Working-Class Families from the Industrial Revolution to the Fertility Decline (London: Verso, I993), II 2. 
To ensure themselves against various threats to their life situations and to improve the lots of their families, better-off workers began organizing mutual aid societies and cooperatives, and later trade unions. Their growing power, plus the ruling elites' increasing fear of new dangers to their positions, led to the introduction of social legislation-usually starting with accident insurance and ending with unemployment insurance. In this way, a substantial part of the working class became protected for the first time.

Before 1939 but especially after the Second World War, when capitalist economies experienced unprecedented growth and the expansion of social security programs became possible, a large part of the working classes in Western Europe, North America, Australasia, and Japan obtained standard employment relationships. This was partly because large corporations realized that the creation of stable labor relations required giving up "short-run output and efficiency in favor of long-run stability and predictability." 21 This labor relationship was normally understood in a gendered way and went together with the increasing acceptance of the male breadwinner model. ${ }^{22}$ A gendered division of labor emerged: standard employment mainly concerned men, while in other kinds of labor relationships women were overrepresented. Even more so than in the past, precarious labor became a female occupation.

\section{“Overunemployment" and Precarious Labor in the Global South}

In the course of the twentieth century, and especially since the I940s, the number of unemployed and underemployed in the global South grew by leaps and bounds. Economic historian Paul Bairoch estimated in the middle of the I980s that in Latin America, Africa, and Asia, "total inactivity" was "on the order of $30-40 \%$ of potential working man-hours" — a situation without historical precedent, "except perhaps in the case of ancient Rome." ${ }^{23}$ In Europe, North America, and Japan, the average level of unemployment has always been significantly lower, and, as Bairoch conjectures, this level has been cyclical. In contrast, overunemployment in the global South has a structural character. One of the first analysts who drew attention to this reality was the Peruvian sociologist Anibal Quijano Obregón, who argued that the tens of millions of permanently "marginalized" workers in the global South could no longer be regarded as a "reserve army" in the Marxian sense, because their social condition lacked any "periodicity" and because they formed no "mass of human material

21. Sanford M. Jacoby, Employing Bureaucracy: Managers, Unions, and the Transformation of Work in American Industry, 1900-1945 (New York: Columbia University Press, 1985), 28I.

22. See, among others, Angelique Janssens, ed., "The Rise and Decline of the Male Breadwinner Family?" special issue, International Review of Social History S5 (1997); Birgit Pfau-Effinger, "Socio-historical Paths of the Male Breadwinner Model: An Explanation of Cross-national Differences," British Journal of Sociology 55, no. 3 (2004): 377-99; and Mari Osawa, "The Vicious Cycle of the 'Male Breadwinner' Model of Livelihood Security," Voices from Japan I6 (Winter 2006): I-5.

23. Paul Bairoch, Cities and Economic Development: From the Dawn of History to the Present, trans. Christopher Braider (London: Mansell, I988), 466. 
always ready for exploitation" since their abilities were simply not compatible with those required by capitalist industry. ${ }^{24}$

The history of these large numbers of precarious laborers not only in fastgrowing cities but also in the countryside has rarely been researched comprehensively. It is not that scholars do not find this history an attractive subject to study; quite simply, reliable documentation about it is scarce. The studies that were done tended to focus on the history of the slums in which the precariat lived and their associated housing and poverty problems. The actual labor relations of the precariat received much less attention. ${ }^{25}$ In more recent times, this situation has changed somewhat. At the start of the I970s, anthropologists discovered the informal sector and, after the International Labor Organization accepted the term, this led to quite a few studies about the survival strategies of the urban poor.

There have been many attempts by researchers to define the informal sector accurately, but there is still no consensus about the phenomenon. ${ }^{26}$ The term is vague and misleading, if only because corporations seeking to dodge taxes may deliberately arrange their business matters informally and because there is usually an urban bias (agricultural work is often organized informally too). However, the expression informal sector also has its advantages: it draws attention to the plurality of human survival strategies and to the important roles played by women and children. Regardless of definition, however, precarious labor exists in all sorts of ways within the informal sector. Numerous small enterprises not only use the unpaid labor of family members and friends but also employ many casual laborers. The status of such labor arrangements often does not have the form of a direct employer-employee relationship. Not infrequently, intermediaries play a role, such as delivering raw materials to homebased workers and later picking up the semifinished or finished products or supplying labor gangs to an employer. In an attempt to classify these different activities, Peter Worsley created the following categories:

(a) the huge personal service sector ...; (b) a population of hucksters, itinerant salesmen, lottery agents, shoe shiners, street vendors of all kinds (including children), often mediating between kin or "most-favored" partners in the countryside and

24. Anibal Quijano Obregón, “The Marginal Pole of the Economy and the Marginalised Labour Force," Economy and Society 3, no. 4 (I974): 393-428; and Karl Marx, Capital, vol. I, trans. Ben Fowkes (Harmondsworth: Penguin, 1976), $785-86$.

25. See, for example, Licia Valladares, "A gênese da favela carioca: A produção anterior às ciências sociais," Revista Brasileira de Ciências Sociais 44 (October 200o): 5-34. An exception that proves the rule is K. S. O. Beavon and C. M. Rogerson, "The Persistence of the Casual Poor in Johannesburg," Contree 7 (January I980): I5-2I.

26. This concept was introduced by Keith Hart, "Informal Income Opportunities and Urban Unemployment in Ghana," Journal of Modern African Studies II, no. I (I973): 6I-89. An early but still relevant critique was provided by Jan Breman, "A Dualistic Labour System? A Critique of the 'Informal Sector' Concept," Economic and Political Weekly II, no. 48 (I976): I870-76, and II, no. 49 (I976): I905-8. An influential attempt at a definition was made by Alejandro Portes, "The Informal Sector: Definition, Controversy, and Relation to National Developments," Review [Fernand Braudel Center] 7 (I98I): I5I-74. 
the urban markets, retailing cheap goods and services to the poor among whom they live; (c) workers in sweatshops that can only compete by paying their workers low wages ... ; (d) "putting-out" home employment; (e) domestic production on a family basis; (f) casual laborers (porters, car washers, and so forth); (g) self-employed artisans, such as shoe repairers, service technicians of all kinds, with informal skills and minimal capital; (h) the "hunters and collectors of the urban jungle," refuse dealers, and so forth; (i) criminals and other "deviant" entrepreneurs, notably prostitutes; and (j) beggars and the unemployed. ${ }^{27}$

The boundaries between these different categories are vague. Self-employment is quite often a form of hidden wage labor. A self-employed worker often has only one important client, through which the client becomes a de facto employer. The selfemployed worker is often not the owner of means of production. For example, think of the "street vendors who are provided their wares early in the morning on credit or commission from a wholesale dealer and then in the evening, after returning the unsold remainder, learn if and what they have retained from their transactions." 28

\section{A South-North Convergence?}

The tempestuous economic growth of the I950s and ig6os created the impression that capitalism had at last become "social." The average income level of households grew with unprecedented speed, labor mobility became much easier, and the level of consumption increased so fast that many social scientists started to believe that the old class society had elevated itself to a higher level and that work had lost its central place in social development. Some intellectuals argued that the old class system no longer existed in postindustrial society. Around I990, when the socialism of the Eastern Bloc countries collapsed, many commentators believed that the victory of liberal and social capitalism was final. "The end of history" seemed to have arrived, with a socially conscious liberal democracy as its absolute summit. However, the opposite turned out to be true. The downfall of state-socialist competitors provided a powerful boost to market fundamentalism, which accelerated a process of economic liberalization that had already begun in the West some ten years earlier. Economic and social inequality began to rise steadily in the West, and, aside from rather brief speculative booms, overall economic growth slowed down.

The standard employment relationship in the global North is now being broken down - step by step, consistently. In his presidential address to the American Sociological Association some years ago, Arne Kalleberg summarized the causes as follows:

27. Peter Worsley, "Social Class and Development," in Social Inequality: Comparative and Developmental Approaches, ed. Gerald Berreman (New York: Academic Press, I98I), 22I-55, at 24I.

28. Jan Breman, At Work in the Informal Economy of India (New Delhi: Oxford University Press, 2013), 32 . 


\begin{abstract}
The process that came to be known as neoliberal globalization intensified economic integration, increased the amount of competition faced by companies, provided greater opportunities to outsource work to low-wage countries, and opened up new labor pools through immigration. Technological advances both forced companies to become more competitive globally and made it possible for them to do so.... Unions continued to decline, weakening a traditional source of institutional protections for workers and severing the postwar business-labor social contract. Government regulations that set minimum acceptable standards in the labor market eroded, as did rules that governed competition in product markets. ${ }^{29}$
\end{abstract}

Altogether, the balance of power shifted in favor of the employers. In countries belonging to the Organization of Economic Co-operation and Development (OECD), the relative proportion of precarious workers has steadily increased at the same time. A 2004 report of the European Union concluded "that in most countries precarious employment has increased over the last two decades." ${ }^{30}$ The same seems to apply to the United States and Canada. ${ }^{31}$

Standard employment is becoming scarcer in advanced capitalist countries too, and it seems to be even more a male privilege than was the case previously. ${ }^{32}$ Labor relations in rich countries are beginning to look much like those of poor countries. The current demolition of "social capitalism” confirms an insight about longterm developments that István Mészáros stated as follows:

The objective reality of different rates of exploitation — both within a given country and in the world system of monopoly capital —is as unquestionable as are the objective differences in the rates of profit at any particular time.... All the same, the reality of the different rates of exploitation and profit does not alter the fundamental law i.e., the growing equalization of the differential rates of exploitation as the global trend of development of world capital. ${ }^{33}$

The fierce, increasingly global competition between capitals now has a clear downward equalizing effect on the quality of life and work in the more developed parts of global capitalism.

29. Arne L. Kalleberg, "Precarious Work, Insecure Workers: Employment Relations in Transition," American Sociological Review 74 (February 2009): I-22.

30. Precarious Employment in Europe: A Comparative Study of Labour Market-Related Risks in Flexible Economies (Brussels, Belgium: European Commission, 2004), 58-59.

3r. See, for example, Kalleberg, "Precarious Work, Insecure Workers"; T. Alterman et al., "Prevalence Rates of Work Organization Characteristics among Workers in the U.S.: Data from the 2010 National Health Interview Survey," American Journal of Industrial Medicine 56, no. 6 (2013): 647-59; and Diane-Gabrielle Tremblay, "From Casual Work to Economic Security: The Paradoxical Case of SelfEmployment," Social Indicators Research 88, no. I (2008): I15-30.

32. A pioneering study was done by Lourdes Benería, "Shifting the Risk: New Employment Patterns, Informalization, and Women's Work," International Journal of Politics, Culture, and Society 15, no. I (200I): 27-53; and an international comparative perspective is offered by Leah F. Vosko, Martha MacDonald, and Iain Campbell, eds., Gender and the Contours of Precarious Employment (New York: Routledge, 2009).

33. István Mészáros, Beyond Capital: Towards a Theory of Transition (London: Merlin Press, I995), 89I. 
Nevertheless we should keep in mind that, globally and historically, there are different kinds of precarization. I provisionally suggest there are at least three basic variants:

I) Before the arrival of standard employment, precarious labor in advanced capitalism was restricted to particular limited sectors of national economies and had mainly a temporary and conjunctural character.

2) Precarious labor in contemporary advanced capitalism has spread to all sectors and is now less conjunctural and more an effect of international competition, but it combines with some labor protection - by means of laws and welfarestate regulations established from the I940s to the I97os, which still remain in force even if they are being whittled away.

3) Precarious labor in the global South has spread to almost all sectors, is especially structural in nature, and is to an important degree an effect of international competition. This variant involves a far greater number of people and offers much less formal protection than that given to precarious labor in the global North. In addition - and partly in consequence of this differencethe income differences between precarious workers in the North and the South remain gigantic.

Precarious labor before the Second World War and the postwar boom of the capitalist economy was an effect of a temporary oversupply of labor; contemporary precarious labor in the North and the South looks to be much more persistent and structural, due to a rapid growth of the productive forces worldwide that enable much more output to be produced with much less labor. ${ }^{34}$ This development reminds us that standard employment under capitalist conditions is a historical anomaly. Immanuel Wallerstein pointed out that employers always have an interest in workers having multiple income sources because that enables remuneration for each particular job at lower rates. That is why, Wallerstein argues, "the location of wage-workers in semiproletarian rather than in proletarian households has been the statistical norm." ${ }^{35}$

\section{Organizing the Precariat}

Despite initial reluctance, trade unions have been persuaded of the need for action. An ILO report once spoke sincerely about "peripheral workers" "who in the past have been viewed as a threat to the security of the core, unionized workers," whereas the unions now "recognize the urgent need to organize them." 36 At the r988 World Congress of the International Confederation of Free Trade Unions (ICFTU) in Mel-

34. This is also a central thesis in the work of the sociologist Ulrich Beck, Schöne neue Arbeitswelt (Munich: Beck, 200o).

35. Immanuel Wallerstein, Historical Capitalism with Capitalist Civilization, and ed. (London: Verso, I995), 27.

36. Shauna L. Olney, Unions in a Changing World: Problems and Prospects in Selected Industrialized Countries (Geneva, Switzerland: International Labour Office, I996), 2 I. 
bourne, a report declared that "viewed from a global perspective one, if not the major, challenge facing trade unions is the organising of vast numbers of workers in rural areas and in the 'informal sectors' in developing countries." ${ }^{37}$

Such lofty appeals have generated hardly any tangible results, however. The very small influence of trade unions among the precariat is mainly due to what Adolf Sturmthal called "a naive belief in the universal applicability of some form of collective bargaining." 38 That belief clashes with the reality of workers who are constantly changing jobs, earn very irregular incomes, and sometimes do not even aim for longterm standard employment but instead pursue a "flexicurity" that provides the benefits but not the disadvantages of labor market fluidity. In Japan, a large group of young precarious workers in the late I980s and I99os came to be known as the freeters (furìtā, a transcription written in katakana), meaning people either unable or unwilling to hold regular employment. (This Japanese neologism is possibly a conjunction of the English free and the German Arbeiter). ${ }^{39}$

To be sure, there are also unions that, via coalitions with community groups, succeeded in organizing precarious workers. ${ }^{40}$ In many places, there have been spontaneous attempts by precarious workers to form mutual aid societies that arrange financial support in cases of illness, etc. - a form of organization already known in earlier phases of the labor movement. ${ }^{41}$ For example, the Self-Employed Women's Association in Gujarat (India), which has a membership of more than a million female precarious laborers, is famous. ${ }^{42}$

The social void that labor organizations have allowed to emerge is partly filled by religious and nationalist movements, which offer their supporters elementary forms of social security and trust networks, as well as self-esteem and clear life goals. Parts of the precariat are drawn into such movements, in all their variantsfrom the Pentecostalist movements of Latin America and sub-Saharan Africa to Salafism in North Africa, the Middle East, and Central Asia. Precarious youth in capitalist industrial cities likewise appear to be attracted to groups offering religious certainty. A typical example is the Hindu-fascist Shiv Sena movement, which gained influence after the defeat of the big textile workers strike in Bombay in I980-8I. The social plagues of casualization—immiseration, petty crime, and trafficking — quickly

37. The Challenge of Change (Brussels, Belgium: ICFTU, I988), 86.

38. Adolf Sturmthal, "Industrial Relations Strategies," in The International Labor Movement in Transition, ed. Adolf Sturmthal and James G. Scoville (Urbana: University of Illinois Press, I973), I-33, at 5.

39. Kosugi Reiko, "Youth Employment in Japan's Economic Recovery: 'Freeters' and 'NEETs."' Asia Pacific Journal: Japan Focus, May I I, 2006, www.japanfocus.org/-kosugi-reiko/2022.

40. Canadian examples are provided in Cynthia J. Cranford et al., eds., Self-employed Workers Organize: Law, Policy, and Unions (Montreal, Canada: McGill-Queen's University Press, 2005), and Pradeep Kumar and Christopher Schenk, eds., Paths to Union Renewal: Canadian Experiences (Peterborough, Canada: Broadview Press, 2006)

4I. See, for example, Marcel van der Linden, Workers of the World: Essays toward a Global Labor History (Leiden, the Netherlands: Brill, 2008), chaps. 5 and 6.

42. See www.sewa.org. 
made the Shiv Sainiks popular. They offered the poor not only honor, status, and selfrespect but also cooperated with yellow "trade unions," which gave some protection. ${ }^{43}$

San Precario's irony seems to turn this upside down. An Italian exclamation of despair in hopeless situations is "non so a che santo votarmi" - "I don't know which saint to pray to." San Precario seems to answer: "Precarious workers of the world, unite and fight for a life fit for human beings!"

43. Gérard Heuzé-Briugant, "Populism and the Workers Movement: Shiv Sena and Labour in Mumbai," South Asia: Journal of South Asian Studies 22, no. 2 (1999): I19-48. 
Published by Duke University Press 